Provided for non-commercial research and education use. Not for reproduction, distribution or commercial use.

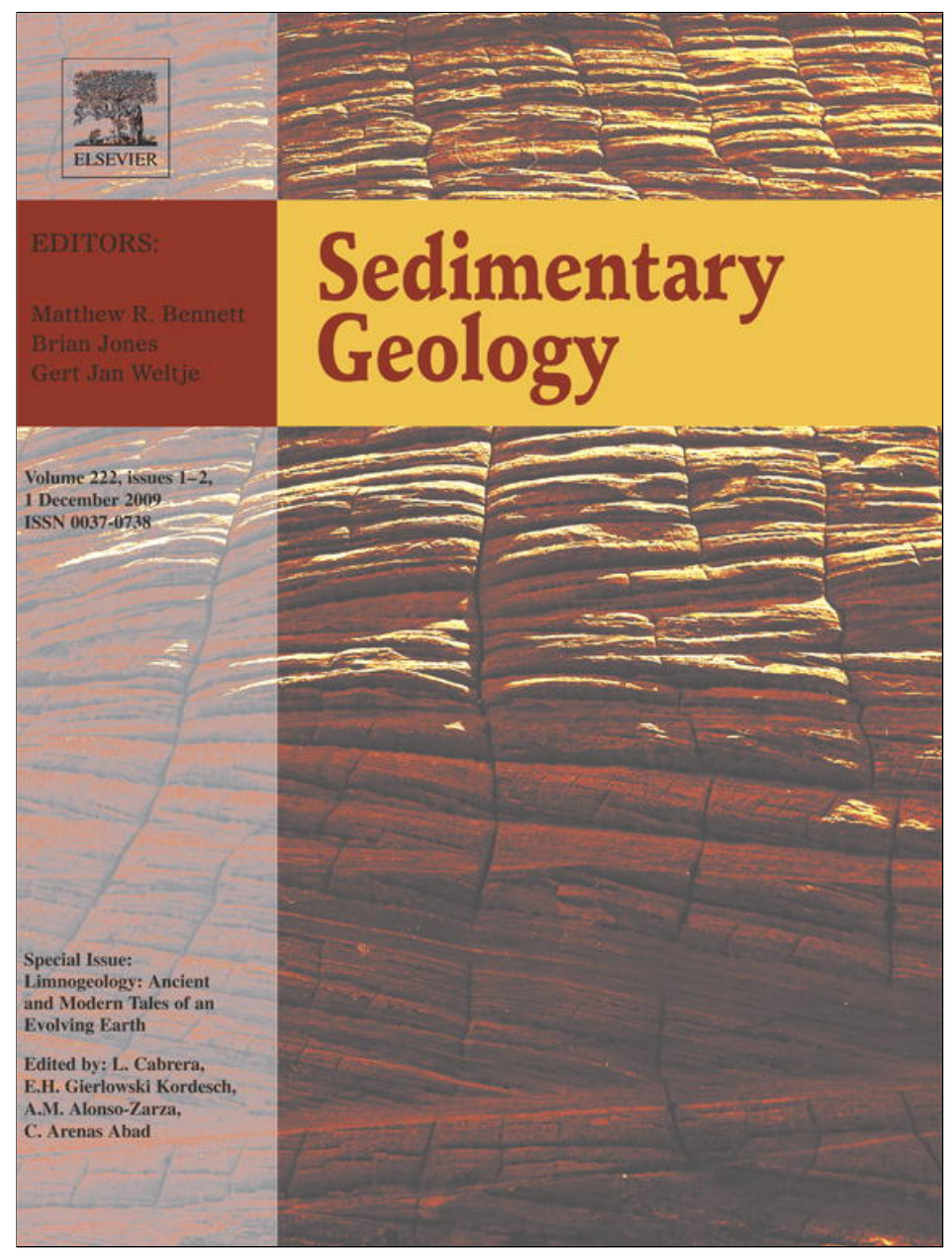

This article appeared in a journal published by Elsevier. The attached copy is furnished to the author for internal non-commercial research and education use, including for instruction at the authors institution and sharing with colleagues.

Other uses, including reproduction and distribution, or selling or licensing copies, or posting to personal, institutional or third party websites are prohibited.

In most cases authors are permitted to post their version of the article (e.g. in Word or Tex form) to their personal website or institutional repository. Authors requiring further information regarding Elsevier's archiving and manuscript policies are encouraged to visit:

http://www.elsevier.com/copyright 


\title{
Morphotectonic setting of maar lakes in the Campo de Calatrava Volcanic Field (Central Spain, SW Europe)
}

\author{
A. Martín-Serrano a, J. Vegas ${ }^{\text {b,* }}$, A. García-Cortés ${ }^{\text {b }}$, L. Galán ${ }^{\text {a }}$, J.L. Gallardo-Millán ${ }^{\text {c }}$, S. Martín-Alfageme ${ }^{\text {a }}$, \\ F.M. Rubio ${ }^{\text {a }}$, P.I. Ibarra ${ }^{\text {a }}$, A. Granda ${ }^{\text {d }}$, A. Pérez-González ${ }^{\text {e }}$, J.L. García-Lobón ${ }^{\text {a }}$ \\ a Instituto Geológico y Minero de España (IGME), E-28760-Tres Cantos, Madrid, Spain \\ ${ }^{\mathrm{b}}$ Instituto Geológico y Minero de España (IGME), E-28003-Madrid, Spain \\ c Department of Geological and Mining Engineering, Castilla-La Mancha University, E-13400-Almadén, Ciudad Real, Spain \\ ${ }^{\mathrm{d}}$ International Geophysical Technology (IGT Inc.), E-28700-San Sebastián de los Reyes, Madrid, Spain \\ e Centro Nacional de Investigación sobre la Evolución Humana (CENIEH), E-09004-Burgos, Spain
}

\section{A R T I C L E I N F O}

\section{Keywords:}

Maar lakes

Phreatomagmatic eruptions

Electrical tomography

Neogene

\begin{abstract}
A B S T R A C T
In the Campo de Calatrava Volcanic Field (CCVF, Central Spain), the eruption of Pliocene-Pleistocene maar craters into two clearly distinct types of pre-volcanic rocks allows the observation and comparison of hardsubstrate and soft-substrate maar lakes. Hard-substrate maars formed when phreatomagmatic processes affected the jointed, Paleozoic igneous and metamorphic rocks (hard substrate), giving rise to funnel-like maar lake basins. Soft-substrate maars resulted from phreatomagmatic volcanic processes affecting poorlyconsolidated Pliocene sediments, forming bowl-like maar lake basins. Pre-volcanic bedrock determined the post-eruptive lacustrine architecture in the craters and favored a higher preservation of hard-substrate maars in comparison to soft-substrate maars. This is because the hard-substrate maars, surrounded by a deep stable crater wall, are more capable of collecting sediments in their basins. These sediments could be preserved for longer than similar deposits in broad, shallow maars with a soft substrate. Ancient soft-substrate maars do not usually preserve their original morphology well and can be identified only by their lacustrine deposits. Carbonate lacustrine/palustrine deposits surrounding a bowl-like depression are the remnants of this second type of maar lake, and allow reconstruction of the original morphology of ancient soft-substrate maar craters. Geophysical (electrical tomography ground surveys) and geomorphologic-geologic mapping techniques were combined with fieldwork and facies analysis in order to locate and accurately characterize the PliocenePleistocene soft-substrate maar volcanic structures of the CCVF.
\end{abstract}

(C) 2009 Elsevier B.V. All rights reserved.

\section{Introduction}

Maars are a special type of volcanic structure formed by phreatomagmatic processes, characterized by circular craters, often filled with water and sediments and surrounded by a ring of pyroclastic deposits (Schmincke, 1988; Büchel, 1993). The entire volcano, including the tephra ring surrounding the maar crater, is called a maar-diatreme volcano (Lorenz, 1975; Lorenz, 1985). All terms are used in a purely descriptive, non-genetic way, and do not connote a specific emplacement process. More than any other type of volcanic activity, maar volcanism is strongly affected by the near-surface geologic setting (e.g. Lorenz et al., 1970; Kienele et al., 1980; Self et al., 1980; Lorenz, 1986; White, 1991; Aranda-Gómez and Luhr, 1996; Gevrek and Kazanci, 2000; Németh et al., 2001). Phreatomagmatic eruption mechanisms and the geology of maar-diatreme structures have been comprehensively discussed in several papers (e.g. Fisher and Schmincke, 1984; Lorenz,

\footnotetext{
* Corresponding author. Fax: +34 913495834.

E-mail address: j.vegas@igme.es (J. Vegas).
}

1986; Lorenz et al., 2003; Wohletz and Zimanowski, 2000; Pirrung et al., 2003).

The detection of preserved maar structures is important not only for underground mapping, but also for paleoclimate research, since laminated maar lake sediments may contain very detailed archives of climate and environmental history in continental areas (e.g. Dodson, 1974; Negendank and Zolitschka, 1993; Creer and Thouveny, 1996; Roberts et al., 2001; Liu et al., 2001; Wagstaff et al., 2001; Caballero et al., 2003; Lücke and Brauer, 2004; Mingram et al., 2004; Schulz et al., 2005; Crausbay et al., 2006; Garcin et al., 2006; Zolitschka et al., 2006; Pirrung et al., 2008). The advantage offered by maar lake records is their high temporal resolution; their morphology favors the rapid and continuous accumulation of sediments (Gasse et al., 1997; Allen et al., 1999). Maar lake basins have a relatively small drainage basin, uniform geology, and a simple hydrologic regime. Most of them have sediments with annual lamination, which can be employed as an independent chronologic system.

In general terms, volcanic eruption style is primarily controlled by eruption rate, magmatic gas content, viscosity of magma, and magmatic source - basically the "source and en route" processes. Maar formation is 
affected by near-surface conditions, namely the physical parameters of the shallow substrate. Moreover, the potential eruption style (effusive versus phreatomagmatic) is strongly controlled by the host rock environment which the mafic melt encounters (Connor et al., 2000). Pre-volcanic country rocks control the morphology of maar formation and their related maar lake basins. Phreatomagmatic explosions take place simply because magma heats various groundwater aquifers. Two contrasting environments exist with regard to groundwater availability for phreatomagmatic explosions: (1) the "hard-rock" environment, which is a joint aquifer, and (2) the "soft-rock" environment, which is a pore aquifer (Lorenz, 2003). The water saturation (and style of water storage, e.g. porous media-soft rock, or fracture-controlled-hard rock aquifers) of the substrate will affect the potential for the occurrence of magma-water interaction, and, as a consequence, the phreatomagmatism. The "soft-rock environment" is a term used to refer to loose and water-saturated country rocks and sediments that the feeding dikes intrude, and which may enhance phreatomagmatism (Lorenz, 1985, 2002).

Both maar types (Figs. 1 and 2) have been identified in the Campo de Calatrava Volcanic Field (CCVF) (Ancochea, 1983; Poblete, 1995; MartínSerrano et al., 2007). In hard-substrate maars, the explosive volcanic processes affected the basement metasediments (Precambrian slates and graywackes, Carboniferous sandstones, and Tremadocian-Arenigian (early Ordovician) slates and quartzites) with magma interacting with water in joint aquifers. On the other hand, in soft-substrate maars, the explosive volcanic processes affected the thick poorly-consolidated, fluvio-lacustrine Pliocene sediments (arkosic sands, marls, and silts). Thus, maar lake basins are controlled by the pre-volcanic environment.

Hard-substrate maars, surrounded by a deep stable crater wall, are more capable of collecting sediments in their basins which could be preserved for longer than similar lacustrine deposits in a broad, shallow maar formed in a soft-substrate environment. This situation favors a higher preservation of hard-substrate maar lakes because their country rocks are more resistant to collapse and erosion, as opposed to softsubstrate maars where the less resistant materials can subside and collapse into the newly-formed depression. Also, the surface morphology of soft-substrate maars is changed more easily, after eruption, by erosion and compaction, or is hidden by younger sediments. Ancient soft-substrate maar basins can be identified by their lacustrine infill (Martín-Serrano et al., 2007; Németh et al., 2008), or their exposed diatreme and peperitic zones (Auer et al., 2007; Németh and Martin, 2007). Maar crater morphologies, and, thus, maar lake basin size, erosion-sedimentation processes, and lacustrine facies are clearly determined by the pre-volcanic country rocks.

The Valverde de Calatrava area of Central Spain is studied here because its Campo de Calatrava Volcanic Field features both types of pre-volcanic maars and their related lakes. The post-eruptive sedimentation-erosion history of maars has not yet been studied in detail, and clues to the relationship between phreatomagmatism and subsequent maar lake formation and evolution can confirm the differences in maar development in soft- and hard-substrate areas.

\section{Site description and geology}

The study site is mainly located in the Ciudad Real Province of Central Spain, in the area known as the Campo de Calatrava Volcanic Field (CCVF) in the Central Volcanic Region (Hernández-Pacheco, 1932; Ancochea, 1983) (Fig. 1). Volcanism of the CCVF developed individual small-volume mafic volcanoes in a continental monogenetic volcanic field where maar craters, scoria cones, and lava flows are the most abundant features. According to $\mathrm{K}-\mathrm{Ar}$ and $\mathrm{Ar}-\mathrm{Ar}$ ages from the lava (Ancochea, 1983; Bonadonna and Villa, 1984), there were at least two volcanic stages. The first stage involves mafic extrusives of ultra-potassic character and occupies the center of the volcanic region with age ranging between 8.7 and $6.4 \mathrm{Ma}$. The second stage contains an alkaline and ultraalkaline volcanism, with its main activity phase between 4.7 and $1.75 \mathrm{Ma}$. Later, there was some volcanic activity in the early Pleistocene that greatly extended the period of volcanic activity in the region, between 1.3 Ma and 0.7 Ma (Gallardo-Millán and Pérez-González, 2000; Gallardo-Millán et al., 2002; Gallardo-Millán, 2004). Large-scale tectonic processes in the CCVF, related to the Alpine Orogeny, affected the Paleozoic basement rocks, forming faults and overthrust faults with NESW and SE-NW trends (Galindo-Zaldívar et al., 1993; Muñoz and de Vicente, 1998). Two main tectonic stages are identified. The first stage is compressional that originated faults with a NE-SW trend, and conjugate faults with a SE-NW trend, all during the Miocene. A second stage was active from the Pliocene to the present day, but was less compressive than the previous one.

According to Lorenz (1985, 2002, 2003), formation of PliocenePleistocene phreatomagmatic maars in the CCVF took place in hard rocks and soft rocks (Fig. 1). Maar craters are lined up according to NW-SE and NE-SW tectonic trends in Central Spain.

\section{Methods}

Geologic and geomorphologic maps at 1:25,000 scale were composed through field work and interpretation of aerial photographs $(1: 18,000)$. For each maar identified in the CCVF, values of maximum and minimum diameters have been measured (Dmax and Dmin, measured from the crest of the tephra ring). Mean radius $(R)$ is calculated as the half of the diameters. The average surface area $(S)$ for craters and their associated lakes $(s)$ was estimated.

Electrical tomography (ET) methods were employed to characterize the internal structure of the maar lake sediments (thickness, sedimentary facies, and sedimentary basin architecture) in two selected maar lakes: i) Fuentillejo Lake, a hard-rock substrate maar, and ii) Galiana palaeolake, a soft-rock substrate maar. The apparent resistivity measurements for the ET study made on Fuentillejo Lake used dipole-dipole electrode configurations. ET equipment consisted of an Iris VIP-3000 transmitter fed by a 4 KVA generator (0.04 and 4 Amperes), Iris Elrec-6 and Elrec-10 transmitters, and steel electrodes. However, measurements for the ET study made on the Galina paleolake used a Lund system (Abem) equipped with a dipole-dipole and Wenner electrode configurations.

A borehole was drilled in 2002 in the sediments of Fuentillejo Lake to recover the $142.4 \mathrm{~m}$-thick lacustrine sequence (FUENT-1 core). Cores were stored in a core repository at $4{ }^{\circ} \mathrm{C}$. Analyses of mineralogy of the lacustrine sediments were carried out by X-ray powder diffraction using a copper K $\alpha$-tube on a XPERT Pro of PANalytical (PTE-RX-004) at IGME laboratories. Authigenic minerals, particle morphologies, and textural relationships were observed by thin sections and scanning electron microscopy (SEM) at Luis Brú Microscopy Center (Universidad Complutense de Madrid). SEM observations were performed with a JEOL JSM 6400 operated at $20 \mathrm{kV}$ and equipped with a Link System energy dispersive X-ray microanalyzer (EDX).

\section{Maar lakes on CCVF hard-rock substrate}

\subsection{Basic features}

A total of 60 hard-substrate maars have been identified on the crystalline Paleozoic basement, and their craters usually are not coalescent. This type originated as the explosive volcanic processes affected the basement metasediments (Precambrian slates and graywackes, Carboniferous sandstones and Tremadocian-Arenigian slates and quartzites) where magma interacted with water in joint aquifers. They commonly show tephra rings composed of pyroclastic deposits with large exotic country rock fragments floating in a finegrained matrix outside crater walls. Half of them are concentrated in the southern part of the CCVF (Fig. 1), and 26 of them do not have lacustrine records because their craters are filled with rock falls.

Surface morphologic measurements of hard-rock substrate maars are indicated in Table 1 and Fig. 3. The average crater radius $(R)$ is 


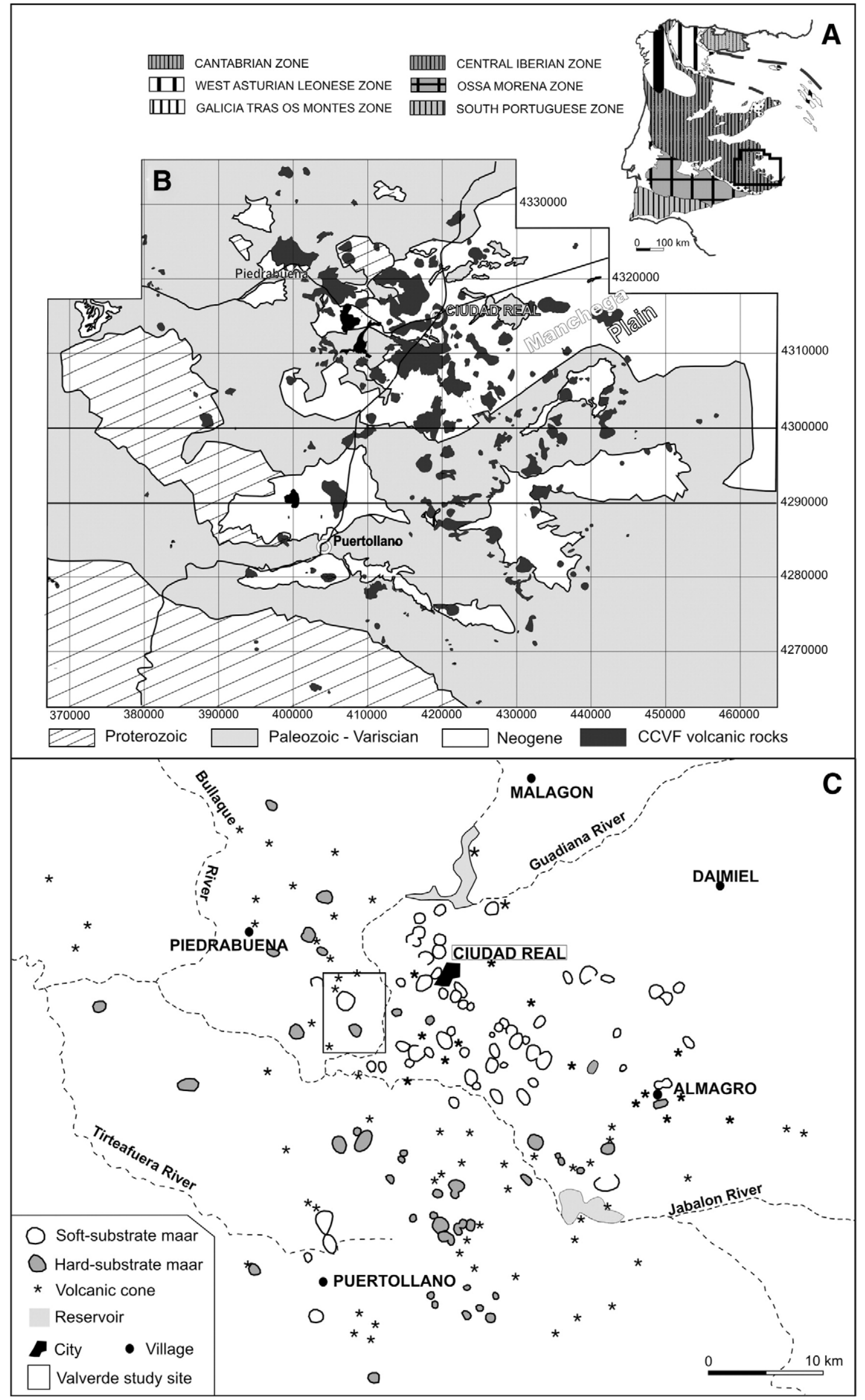


A Hard-substrate maar lakes

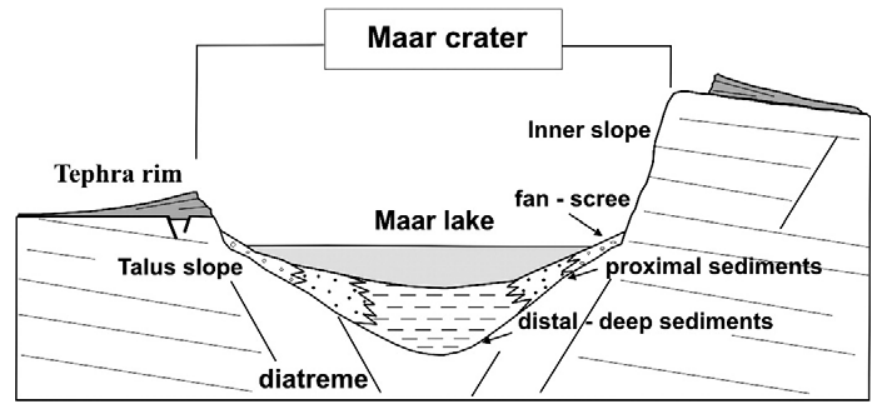

PREVOLCANIC SUBSTRATE

Palaeozoic metasediments

\section{B Soft-substrate maar lakes}

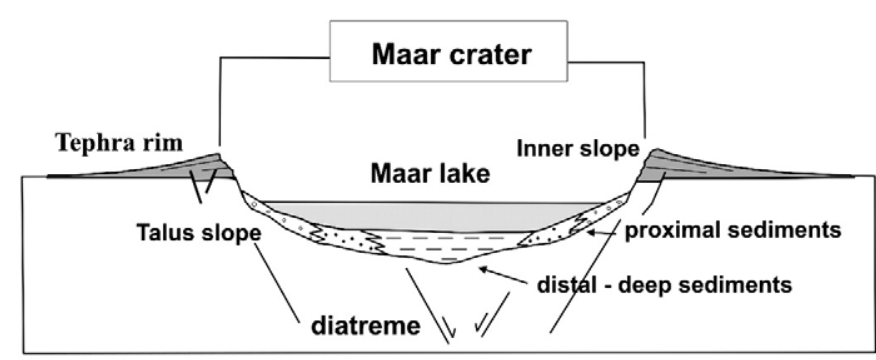

PREVOLCANIC SUBSTRATE

Pliocene detrital sediments

Fig. 2. A. Diagram representative of a hard-substrate maar and related lake type from the CCVF (modified from Büchel, 1993 and Lorenz, 2000). B. Diagram representative of a soft-substrate maar and related lake type from the CCVF (modified from Büchel, 1993; Lorenz, 2000).

$339.4 \mathrm{~m}$, and most of them have an $R$ between 100 and $600 \mathrm{~m}$. Lake basins have a mean radius $(r)$ of $254.7 \mathrm{~m}$, and there is none greater than $500 \mathrm{~m}$. Nevertheless, some craters of large, hard-rock substrate maars have $R=750 \mathrm{~m}$ and $S=1.77 \mathrm{~km}^{2}$ (e.g. La Nava and Caracuel maars). The smallest crater (Cervera maar) has a radius of $88 \mathrm{~m}$ and a surficial area of $0.24 \mathrm{~km}^{2}$. Inner slopes dip towards the interior of the crater, with nearly vertical crater walls comprising slopes of $30^{\circ}$ on interior alluvial fans. Normally in the CCVF, this type of maar basin has a greater inner slope angle than a soft-substrate maar. The internal crater wall usually has a height difference of $120-40 \mathrm{~m}$. Formation of rockfalls, rock slumps, and scree material is very common.

\subsection{Maar lacustrine deposits}

Hard-substrate maar craters have a circular shape and host lakes in the post-eruptive stage with their funnel-like shape (Fig. 2). Such cone-shaped structures cut sharply into the "hard rock" hills, providing a competent and stable substrate for lake basin development. These types of maar lakes are ephemeral closed systems today with the largest maar lakes drained for farming.

Fuentillejo Lake has been chosen here as a model for hardsubstrate maar lakes in the CCVF (Fig. 4). This maar is associated with a pyroclastic flow that includes more than $5 \%$, and rarely up to $30 \%$, of country rock fragments (quartzites and slates), indicating basement excavation. Xenocrysts of olivine and amphibole are common in the entire pyroclastic succession, but large crystals of amphibole $(>5 \mathrm{~cm})$ are more common close to the crater rim.
Table 1

Measurements made on hard-rock maar craters and their maar lakes from Campo de Calatrava Volcanic Field.

\begin{tabular}{|c|c|c|c|c|c|c|c|c|c|}
\hline$D \max$ & Dmin & $d \max$ & $d \min$ & Mean $R$ & Mean $r$ & $R / r$ & $S$ & $s$ & $S / s$ \\
\hline$\overline{1000}$ & 700 & 550 & 550 & 425 & 275 & 1.55 & $567,451.5$ & $237,583.5$ & 2.39 \\
\hline 1150 & 1000 & 700 & 450 & 538 & 288 & 1.87 & $907,627.9$ & $259,672.9$ & 3.50 \\
\hline 1000 & 900 & 550 & 250 & 475 & 200 & 2.38 & $708,823.5$ & 125,664 & 5.64 \\
\hline 750 & 250 & - & - & 250 & - & - & $196,350.0$ & - & - \\
\hline 250 & 225 & - & - & 119 & - & - & $44,264.2$ & - & - \\
\hline 1250 & 1200 & 900 & 550 & 563 & 363 & 1.55 & $994,021.9$ & $412,825.9$ & 2.41 \\
\hline 400 & 250 & - & - & 163 & - & - & $82,957.9$ & - & - \\
\hline 450 & 400 & - & - & 213 & - & - & $141,862.9$ & - & - \\
\hline 1050 & 950 & 450 & 250 & 500 & 175 & 2.86 & $785,400.0$ & $96,211.5$ & 8.16 \\
\hline 550 & 475 & - & - & 256 & - & - & $206,290.2$ & - & - \\
\hline 350 & 300 & - & - & 163 & - & - & $82,957.9$ & - & - \\
\hline 450 & 450 & - & - & 225 & - & - & $159,043.5$ & - & - \\
\hline 750 & 700 & - & - & 363 & - & - & $412,825.9$ & - & - \\
\hline 1700 & 1500 & 1150 & 700 & 800 & 463 & 1.73 & $2,010,624.0$ & $672,007.9$ & 2.99 \\
\hline 1000 & 550 & 600 & 300 & 388 & 225 & 1.72 & $471,730.9$ & $159,043.5$ & 2.97 \\
\hline 950 & 400 & 550 & 400 & 363 & 238 & 1.53 & $412,825.9$ & $177,205.9$ & 2.33 \\
\hline 1050 & 900 & 850 & 550 & 488 & 350 & 1.39 & $746,620.9$ & 384,846 & 1.94 \\
\hline 650 & 300 & 500 & 150 & 238 & 163 & 1.46 & $177,205.9$ & 82957.9 & 2.14 \\
\hline 400 & 200 & - & - & 150 & - & - & $70,686.0$ & - & - \\
\hline 1150 & 500 & 700 & 350 & 413 & 263 & 1.57 & $534,562.9$ & $216,475.9$ & 2.47 \\
\hline 275 & 250 & - & - & 107 & - & - & $35,632.8$ & - & - \\
\hline 200 & 150 & - & - & 88 & - & - & $24,052.9$ & - & - \\
\hline 1400 & 1350 & 500 & 400 & 438 & 225 & 1.94 & $601,321.9$ & $159,043.5$ & 3.78 \\
\hline 1650 & 1575 & 1100 & 900 & 375 & 250 & 1.50 & $441,787.5$ & 196,350 & 2.25 \\
\hline 500 & 450 & - & - & 238 & - & - & $177,205.9$ & - & - \\
\hline 400 & 400 & - & - & 200 & - & - & $125,664.0$ & - & - \\
\hline 1650 & 700 & - & - & 588 & - & - & $1,084,342.9$ & - & - \\
\hline 1350 & 1000 & 800 & 600 & 588 & 350 & 1.68 & $1,084,342.9$ & 384,846 & 2.82 \\
\hline 1250 & 800 & 750 & 500 & 725 & 313 & 2.32 & $1,651,303.5$ & $306,796.9$ & 5.38 \\
\hline 650 & 450 & 400 & 200 & 275 & 150 & 1.83 & $237,583.5$ & 70,686 & 3.36 \\
\hline 650 & 450 & 400 & 200 & 275 & 150 & 1.83 & $237,583.5$ & 70,686 & 3.36 \\
\hline 350 & 325 & 250 & 200 & 169 & 113 & 1.50 & $89,409.0$ & $39,760.9$ & 2.25 \\
\hline 800 & 600 & 450 & 400 & 350 & 21 & 1.65 & $384,846.0$ & $141,862.9$ & 2.71 \\
\hline 650 & 400 & 300 & 250 & 263 & 138 & 1.91 & $216,475.9$ & $59,395.9$ & 3.64 \\
\hline 1400 & 1250 & 950 & 750 & 663 & 425 & 1.56 & $1,378,867.9$ & $567,451.5$ & 2.43 \\
\hline 1250 & 1150 & 1000 & 850 & 600 & 463 & 1.30 & $1,130,976.0$ & $672,007.9$ & 1.68 \\
\hline 600 & 500 & 350 & 200 & 275 & 138 & 2.00 & $237,583.5$ & $59,395.9$ & 4.00 \\
\hline 650 & 550 & 500 & 250 & 300 & 188 & 1.60 & $282,744.0$ & $110,446.9$ & 2.56 \\
\hline 1050 & 950 & 600 & 500 & 500 & 275 & 1.82 & $785,400.0$ & $237,583.5$ & 3.31 \\
\hline 400 & 300 & - & - & 175 & - & - & $96,211.5$ & - & - \\
\hline 600 & 550 & - & - & 288 & - & - & $259,672.9$ & - & - \\
\hline 1600 & 800 & 650 & 600 & 600 & 288 & 2.09 & $1,130,976.0$ & $259,672.9$ & 4.36 \\
\hline 1050 & 900 & 700 & 654 & 488 & 350 & 1.39 & $746,620.9$ & 384,846 & 1.94 \\
\hline 650 & 600 & 350 & 250 & 313 & 150 & 2.08 & $306,796.9$ & 70,686 & 4.34 \\
\hline 500 & 450 & - & - & 238 & - & - & $177,205.9$ & - & - \\
\hline 1050 & 650 & - & - & 425 & - & - & $567,451.5$ & - & - \\
\hline 1250 & 1250 & 750 & 750 & 625 & 375 & 1.67 & $1,227,187.5$ & $441,787.5$ & 2.78 \\
\hline 1150 & 1100 & 500 & 500 & 563 & 250 & 2.25 & $994,021.9$ & 196,350 & 5.06 \\
\hline 1100 & 950 & 700 & 700 & 513 & 350 & 1.46 & $825,160.9$ & 384,846 & 2.14 \\
\hline 900 & 950 & - & - & 463 & - & - & $672,007.9$ & - & - \\
\hline 1750 & 1250 & - & - & 750 & - & - & $1,767,150.0$ & - & - \\
\hline 650 & 650 & - & - & 325 & - & - & $331,831.5$ & - & - \\
\hline 500 & 450 & - & - & 238 & - & - & $177,205.9$ & - & - \\
\hline 1150 & 750 & 650 & 500 & 475 & 288 & 1.65 & $708,823.5$ & $259,672.9$ & 2.73 \\
\hline 300 & 250 & - & - & 138 & - & - & $59,395.9$ & - & - \\
\hline 500 & 450 & - & - & 238 & - & - & $177,205.9$ & - & - \\
\hline 700 & 575 & - & - & 319 & - & - & $319,191.5$ & - & - \\
\hline 1350 & 1250 & 850 & 750 & 650 & 400 & 1.63 & $1,327,326.0$ & 502,656 & 2.64 \\
\hline 1000 & 800 & - & - & 450 & - & - & $636,174.0$ & - & - \\
\hline 1600 & 1300 & 1150 & 750 & 725 & 475 & 1.53 & $1,651,303.5$ & $708,823.5$ & 2.33 \\
\hline
\end{tabular}

For each hard-rock maar identified in the CCVF, values of maximum and minimum diameters have been measured ( $D$ max and Dmin, measured from the crest of the tephra ring). Mean radius $(R)$ is calculated as the half of the diameters. $d$ max, $d$ min and $r$ are values corresponding to their hard-rock maar lakes. The average surface area $(S)$ for craters and their associated lakes $(s)$ was estimated. All measurements were expressed on meters.

Hard-substrate, lake basin morphology has been inferred by three electrical tomography profiles made on the Fuentillejo Lake basin (García-Cortés et al., 2007). The funnel-like morphology of the lake basin was reconstructed using the ET profile and depth from the 


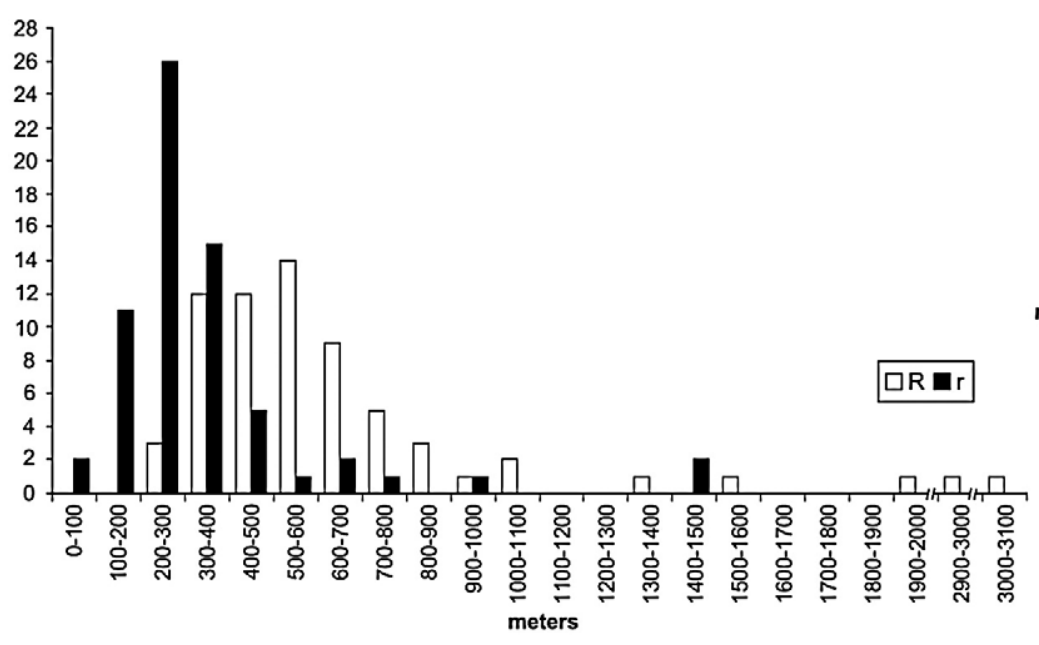

Soft-rock maars
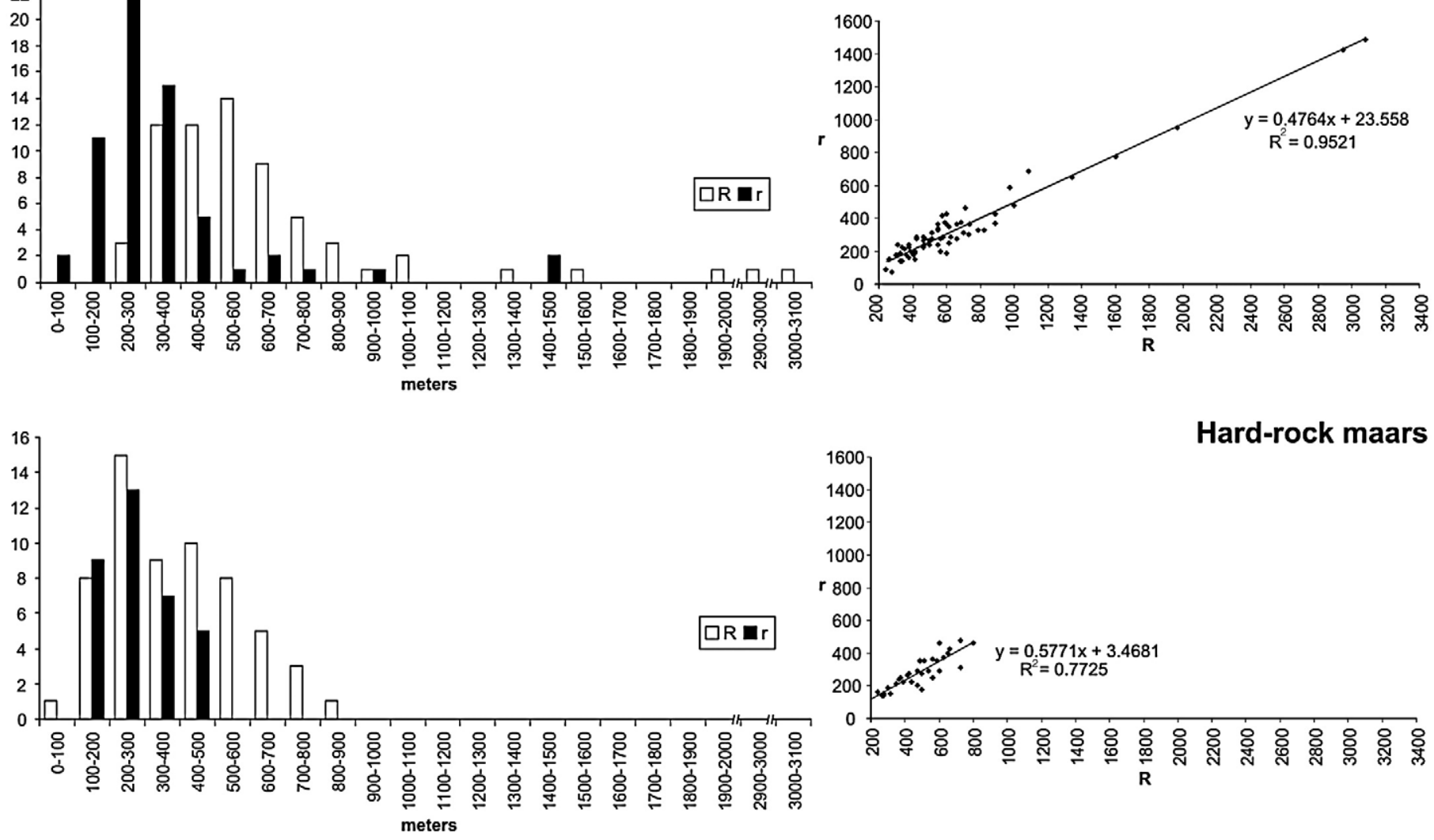

Hard-rock maars

Fig. 3. Plots of frequency of maars with respect to mean radius of craters $(R)$ and mean radius of lake basins $(r)$. Mean radius is calculated as the half main value of maximum and minimum diameters. Dmax and Dmin were measured from the crest of the tephra ring; $d$ max and $d$ min were measured over modern lake surface. Black bars correspond to maar lake basins, and white bars correspond to maar craters.

FUENT-1 core (Fig. 5). Resistivity measurements provided the most detailed information about the internal structure of the maar lake sediments in this site (Fig. 5). An ET-FUENT-1 resistivity profile showed this lacustrine basin to be $90 \mathrm{~m}$ deep, and has also permitted the deduction of interesting aspects of its sedimentary architecture (Fig. 5). Zones of very low resistivity represented distal fine-grained facies of the post-eruptive period.

Pirrung et al. (2003) generalized the lithofacies of maar structures and described five lithozones of typical stages of maar formation within a diatreme structure (A: diatreme breccia, B: syn-eruptive collapse breccia and the maar crater lake sediments, C: debris flow deposits, D: lacustrine laminated sediments with interbedded turbidites, E: peat and deltaic sediments). The $142.4 \mathrm{~m}$ deep research borehole (FUENT-1 core) from the center of Fuentillejo Lake contained a complete lacustrine record corresponding to lithofacies C, D and E of the post-eruptive phases.

Major lithostratigraphic units (total of 23) have been identified in the core, showing variations in clastic input, water chemistry and organic fractions throughout the history of the lake during the upper Pleistocene and Holocene (Vegas et al., 2006). The early lake period is characterized by coarse-grained debris flow and turbidites of higher resistivity values (Fig. 6). Distal lake sediments consist of siliciclastic and organic-carbonate mm-thick rhythmites deposited during high lake level stages. Ephemeral sedimentation periods are indicated by evaporites (mainly consisting in gypsum and carbonate minerals, including dolomite), units of bioturbated massive blue dolomicrites and silts with desiccation horizons. Thick, massive to laminated black oil shale units also occur in units 17 and 20 where the principal source of organic matter is the microalgae Botriococcus braunii.
All carbonate phases are composed of euhedral crystals (2-10 $\mu \mathrm{m})$, suggesting precipitation within the lake (Fig. 7). Dolomite (dolomicrite) formation of primary origin indicates evaporative processes, low lake level, and higher salinity, and is probably linked to a more arid climate. Dolomite, calcite, and zeolites (mainly analcime and minor chabazite-merlinoite; Fig. 7) of primary or early diagenetic origin were identified in the FUENT-1 sequence. The presence of analcime and other zeolites in lacustrine sediments has been interpreted to reflect changes in the salinity and alkalinity of the lake water, induced by climatic shifts (Stoffers and Holdship, 1975).

Las Higueruelas is an example of an ancient, hard-substrate maar lake in the CCVF (Figs. 2 and 8). Outcrops representative of shoreline talus and lacustrine debris flow sediments can be observed in the western area (Fig. 8). The Higueruelas palaeontologic site contains mammalian fossils (mainly Anancus arvernensis, Hipparion rocinantis, Cervus cf. cusanus, Cervus cf. perrieri and Equus df. stenonis) in the uppermost $3 \mathrm{~m}$ of the lacustrine sediments, corresponding to a palustrine mudflat environment (Alberdi, 1984; Arribas and Antón, 1997). Dolomite and zeolites (phillipsite) are the main minerals identified at this site. This maar lake record is $3.5 \mathrm{Ma}$ old, estimated by the application of $\mathrm{K}-\mathrm{Ar}$ methods made on volcanic bombs associated with the fossil bones (Bonadonna and Villa, 1984).

\section{Maar lakes on CCVF soft-rock substrate}

\subsection{Basic features}

Soft-substrate maars of the CCVF exploded within a thick Neogene succession of fluvio-lacustrine sediment, characterized by unconsolidated and water-saturated materials. There is clear evidence of 66 


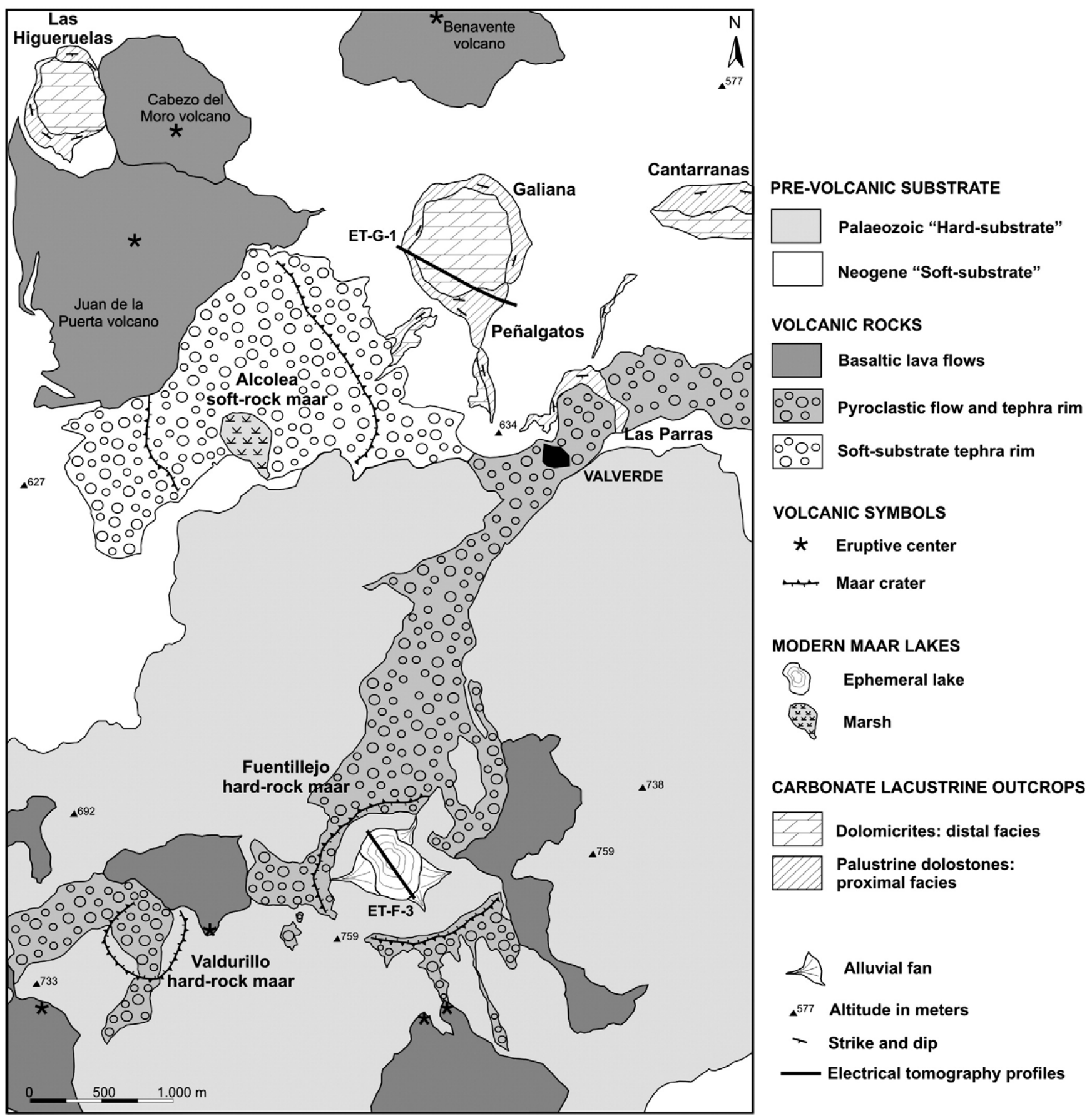

Fig. 4. Simplified geologic map of the pre-volcanic substrate in the Valverde area (selected study site). Fuentillejo and Valdurillo are examples of hard-substrate maars. Alcolea is a preserved, soft-substrate maar. Cantarranas, Peñalgatos, Galiana, and Las Parras paleolakes are examples of ancient, soft-substrate maar lakes. Las Higueruelas is an example of an ancient, hard-substrate maar lake. Electrical tomography profiles were constructed across Fuentillejo (ET-F-3) and Galiana (ET-G-1) lake basins, and they are shown in Figs. 5 and 9 , respectively.

soft-substrate maars in this region (Fig. 1). Their craters usually have a circular shape, but some are elliptical, due to early post-eruptive subsidence and inner wall erosion. Moreover, some of the softsubstrate craters are coalescent (Fig. 1), probably a consequence of surficial unconsolidated material that may provide connected sites for steam release (White and McClintock, 2001; Sohn and Park, 2004). A thin tephra ring usually surrounds the maar craters. They can host a lake basin that resembles a bowl-like shape, providing a good site for water accumulation (Fig. 9).

Surface morphologic measurements (Table 2 and Fig. 3 ) indicate that soft-substrate craters are larger than hard-substrate craters. Soft- substrate craters have an average radius $(R)$ of $565.59 \mathrm{~m}$, and an average surface area $(S)$ of $1.86 \mathrm{~km}^{2}$, while their average maar lake radius $(r)$ is $288.37 \mathrm{~m}$ with a mean surface area of $0.56 \mathrm{~km}^{2}$. The largest softsubstrate craters are significantly larger than hard-substrate craters and have a radius $(R)$ of $3079-2950 \mathrm{~m}$, and $S$ from 1.88 to $5.94 \mathrm{~km}^{2}$ (e.g. Torralba and Granátula maars). Seventy-two percent of craters have a radius ranging from 300 to $700 \mathrm{~m}$ (Fig. 3), and 39.4\% of lakes have a radius of between 200 and $300 \mathrm{~m}$. The radius $(r)$ of the biggest lake is $1485 \mathrm{~m}$, whereas the smallest lake is only $75 \mathrm{~m}$. Craters form walls with shallower angles than the hard-substrate types, and they commonly have collapse structures and sand flows towards the crater center. 


\section{Fuentillejo hard-substrate maar lake basin}
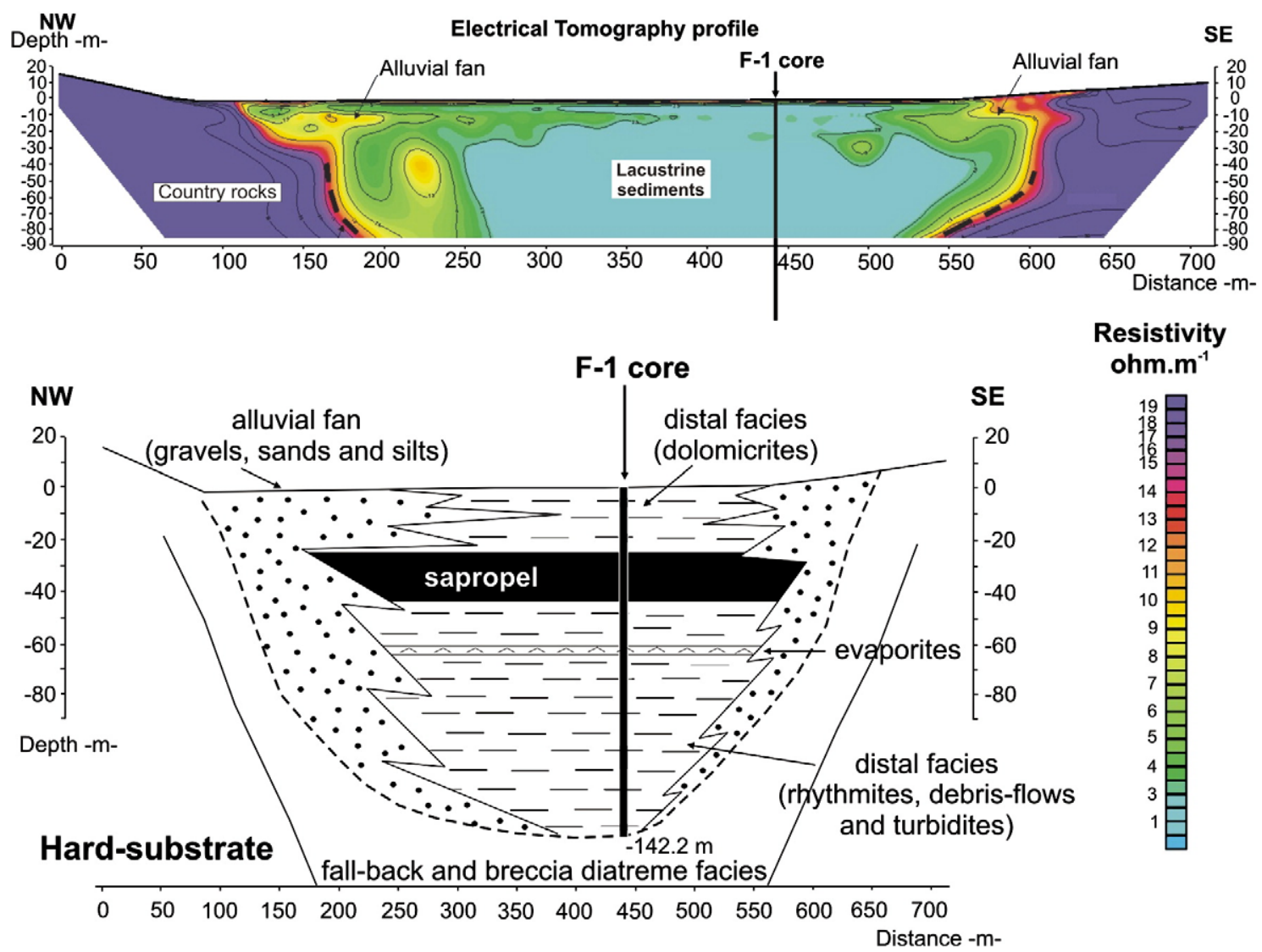

\section{Resistivity \\ ohm.m m $^{-1}$}

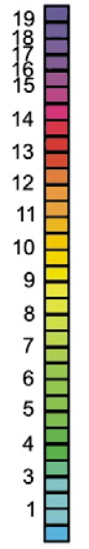

Fig. 5. A. Resistivity profile using electrical tomography in the Fuentillejo hard-substrate lake basin (after García-Cortés et al., 2007). B. Fuentillejo maar lake morphology (intermittent line) has been reconstructed from the electrical tomography interpretation of ET-F-3 profile (in Fig. 4) and the F-1 core of 142.2 m deep (from Vegas et al., 2006).

\subsection{Soft-substrate lacustrine deposits}

Craters have a circular or elongated shape, and always contain a lake basin with a bowl-like shape (Fig. 2), corresponding to the posteruptive period. Circular dolostone rock outcrops outline the ancient soft-substrate volcanic structures in the study site (Fig. 4) corresponding to soft-substrate maar craters filled with lacustrine sediments. Ancient soft-substrate maar lakes in the CCVF are almost filled by post-eruptive sediments and, in some cases, tephra rims are eroded (Martín-Serrano et al., 2007). The surface morphology of the maar structures is changed significantly by erosion and compaction or is hidden by younger sediments (Schulz et al., 2005). Surface measurements on selected dolostone lacustrine outcrops reveal radii $(r)$ that range from 0.9 to $2.2 \mathrm{~km}$, and surface areas from 2.54 to $15.20 \mathrm{~km}^{2}$. These ancient parameters are greater in size than those of modern maars. This could be due to post-eruptive inner wall erosion which enlarged maar craters. Moreover, in soft-substrate maars, compaction of the diatreme fill causes differential subsidence and marginal dragdown of suitable country rock sediments (Francis, 1962; Lorenz, 1971, 2003; Suhr et al., 2006).

We choose Galiana paleolake as an example of an ancient softsubstrate maar lake (Fig. 4). The geologic cartography and ET profiles of the Galiana carbonate paleolake area clearly reveal the bowl-like structure of the maar lake basin (Fig. 9). A detailed electrical tomography survey was carried out to determine the depocenter of this lake basin, where high resistivity values correspond to the lithified carbonate lake sediments. Results from the ET profile indicate a lake depocenter of $60 \mathrm{~m}$ depth (Fig. 9). Subsidence processes can be identified by centripetal dipping angles of nearshore carbonate facies on the TE profile (Fig. 9). Surrounding this bowl-like structure, there are sediments from the Pliocene age which represent the pre-volcanic setting.

The Galiana paleolake sedimentation model may be representative of other soft-substrate maars; other circular carbonate lacustrine outcrops with uncertain stratigraphy positions in the CCVF should be carefully re-examined in the near future. The lacustrine deposits at Cantarranas record the development of another maar lake basin which has been eroded (Figs. 4 and 8). Lithified circular carbonate bodies exhibit a wide variation in morphology as well as in depositional and diagenetic fabric (Vegas et al., 2007). The carbonate mineral suite of softsubstrate maar lake basins consists mainly of dolomite and calcite, with smaller amounts of hydromagnesite and magnesite (Hoyos et al., 1984; Vegas et al., 2007). Zeolites are also present in lacustrine distal facies (analcime and minor chabazite-merlinoite). High $\mathrm{Mg}$ content in carbonate minerals is related to the pyroclastic rocks from the eroded tephra rim. In addition to the carbonates in the distal deep-water facies, the lacustrine basins also contain a girdle of nearshore carbonate. Mottled dolostones from lake girdles reveal subaerial exposure, organisms, root traces, desiccation, and pedogenic features typical of palustrine environments (after Alonso-Zarza, 2003). Palustrine carbonates typically occur in lakes with low gradient, relatively flat surfaces, 
FUENTILLEJO HARD-SUBSTRATE MAAR LAKE RECORD

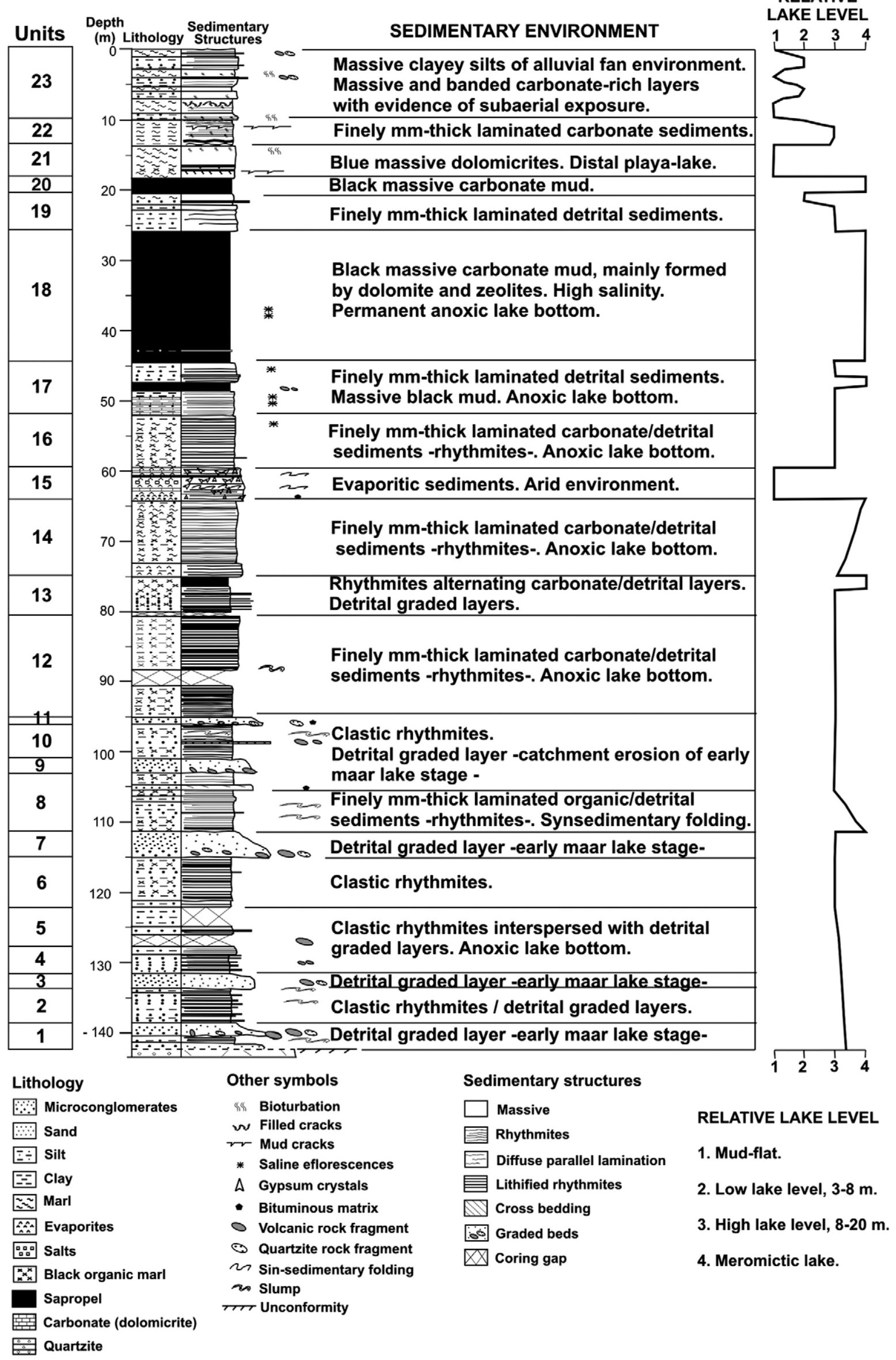


low energy margins, and a carbonate provenance (Platt and Wright, 1991). The primary micrite mud is composed of relatively euhedral dolomite crystals $1-3 \mu \mathrm{m}$ across which were affected by pedogenic modification as the lake level dropped. Cracks are visible under the microscope, and they may remain empty, or be filled with microspar and sparry calcite. Moreover, there are abundant peloids and fenestral structures identified in thin section.

\section{Conclusions}

Hard-substrate and soft-substrate maar volcanoes have been identified in the Campo de Calatrava Volcanic Field (CCVF) through the combination of electrical tomography ground surveys with geomorphologic and sedimentary facies analysis. Maar formation in the CCVF occurred over a long time range from the Pliocene to upper Pleistocene with the resultant basins containing thick sedimentary lacustrine records. Pre-volcanic setting determines maar morphology and post-eruptive lacustrine architecture in the maar craters. The preservational potential of hard-substrate maar showing original volcanic features is greater than that of soft-substrate maars. Steepsided maar lakes with a funnel-like basin form in the hard-substrate settings of Precambrian slates and graywackes, Carboniferous sandstones, and Tremadocian-Arenigian slates and quartzite. In the CCVF, the crater is generally filled with limnic sediments of low density, and mainly fine-upward from meter-thick, detrital graded layers to finely laminated dolomicrite facies.

Unlike hard-substrate maars, soft-substrate maars of the CCVF exploded within a thick succession of Neogene fluvio-lacustrine sediment that is not consolidated as well as water saturated. Craters have a circular or elongated shape and host a lake basin with a bowllike shape. Early lacustrine sedimentation phases contain to detrital graded layers with abundant epiclastic fragments. Later facies
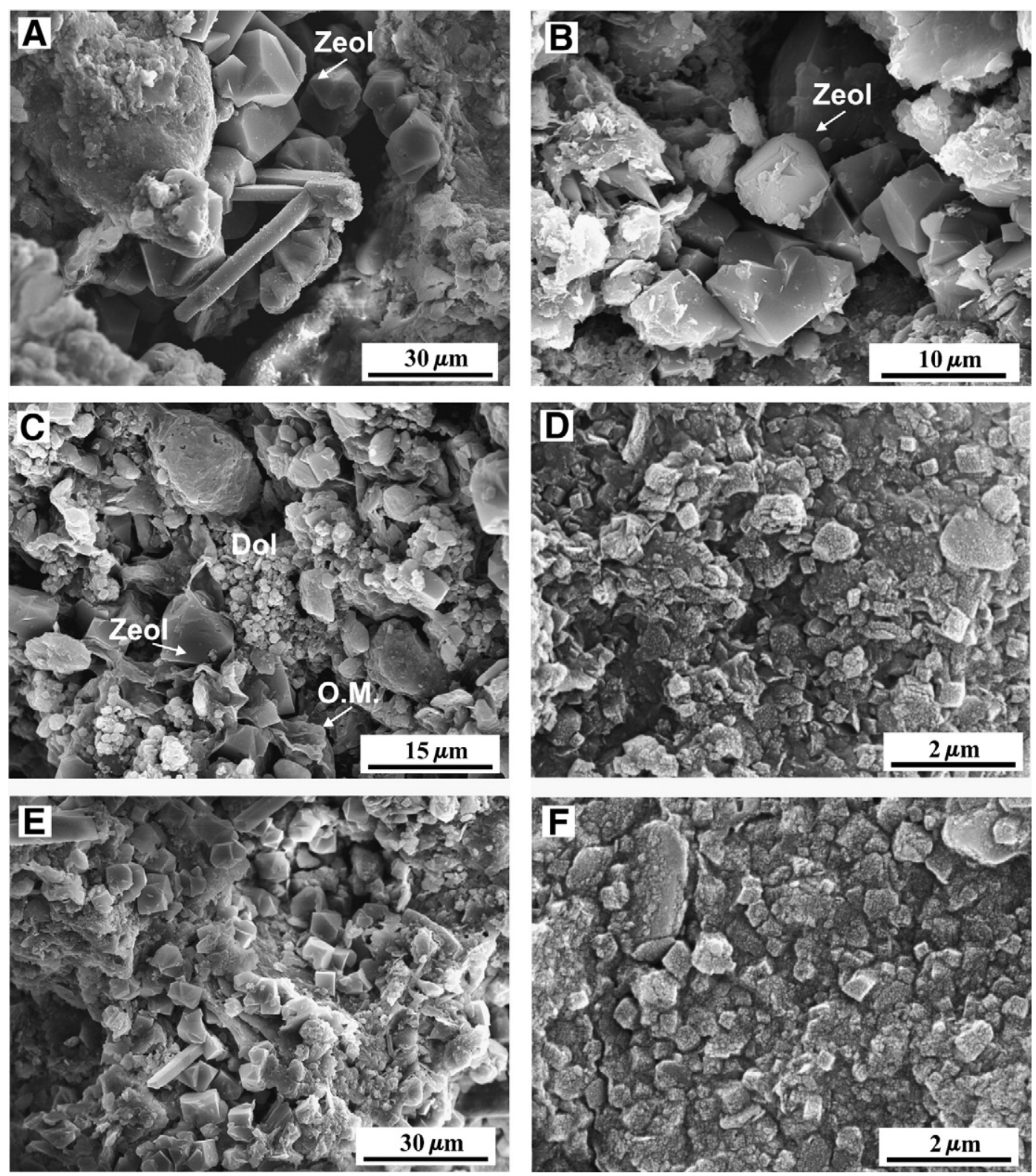

Fig. 7. SEM images: A. Analcime crystals. Blue massive carbonates of Unit 21 (17.42 m deep). B. Analcime crystal on a matrix of detrital kaolinite. Black mud facies of Unit 18 ( $22.69 \mathrm{~m}$ deep). C. Minute primary dolomite rhombi, alternating with analcime and organic matter. Finely laminated carbonate rich sediments with mm-thick laminae from Unit 19 (23.71 m deep). D. Minute dolomite rhombi on a matrix of detrital particles. Massive carbonate-rich layers of Unit 23 ( $8.10 \mathrm{~m}$ deep). E. Lamina with abundant analcime and merlinoite crystals. Finely laminated carbonate-rich sediments with mm-thick laminae from Unit 19 (23.71 m deep). F. Minute dolomite rhombi interpreted as primary in origin. Blue massive carbonates of Unit 21 (15 m deep). 
comprise massive to laminated dolomicrites of a distal origin and mottled dolostones exhibiting subaerial exposure features typical of a nearshore palustrine environment. Dolomite is the main carbonate mineral present in both maar lake types, due to a high influence of volcanic and carbonate catchments.

The shape of both crater types, primarily determined by substrate type, controls lake basin geometry and lacustrine sedimentation patterns. The hard-substrate maars, surrounded by a deep and stable crater wall, can collect sediments and preserve them more effectively. The soft-substrate maars, formed in a less cohesive substrate, contain broad shallow craters with collapse structures and are more exposed to erosive processes. This makes soft-substrate maars more difficult to identify in the landscape; circular outcrops of lacustrine dolostones in the CCVF revealed the location of ancient maars.

The sedimentary records of the maar lakes are influenced by their pre-volcanic substrate as well as climate. Fuentillejo Lake in a hardsubstrate maar has thick black, finely laminated mud sediments corresponding to periods of high lake levels in a high-walled, stable crater. Paleolakes Galiana and Cantarranas, forming in a soft-substrate maar crater, contain mostly shallow lacustrine and palustrine sediments in a shallow broad area with unstable, non-cohesive crater walls.

\section{Acknowledgments}

This work was funded by the Spanish Inter-Ministry Commission of Science and Technology (CICYT), project CGL2004-06212/BTE "Variabilidad climática y ambiental en el centro de la Península Ibérica durante el Cuaternario. Estudio de alta resolución del registro lacustre del sondeo FU-1 (laguna de Fuentillejo, Ciudad Real)" and the IGME through the project CC 54.020 "Estudio Paleoclimático del Maar de Fuentillejo (Ciudad Real)". We thank Elizabeth Gierlowski for her suggestions and language revision. Formal reviews by Károly Németh, an anonymous reviewer, and Lluís Cabrera (Invited Scientific Editor) significantly improved the manuscript, many thanks for it.

\section{References}

Alberdi, M.T. (Coord.), 1984. Geología y Paleontología del yacimiento del Villafranquiense inferior de Las Higueruelas y su entorno (Campo de Calatrava, Ciudad Real). Actas de Castilla-La Mancha. Espacio y Sociedad 3, pp. 229-275.

Allen, J.R.M., Brandt, U., Brauer, A., Hubberten, H.W., Huntley, B., Keller, J., Kraml, M., Mackensen, A., Mingram, J., Negendank, J.F.W., Nowaczyk, N.R., Oberhänsli, H., Watts, W.A., Wulf, S., Zolitschka, B., 1999. Rapid environmental changes in southern Europe during the last glacial period. Nature 400, 740-743.

Alonso-Zarza, A., 2003. Palaeoenvironmental significance of palustrine carbonates and calcretes in the geological record. Earth Sci. Rev. 60, 261-298.

\section{A Las Higueruelas}

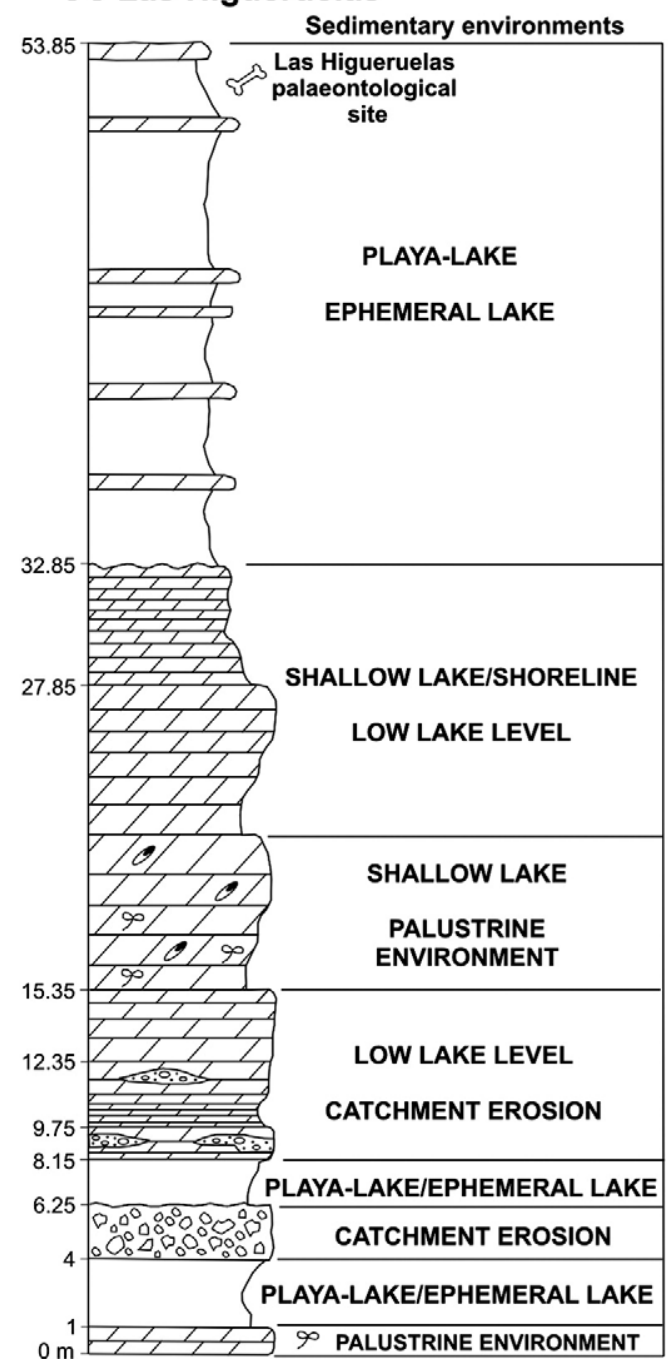

\section{B Cantarranas}

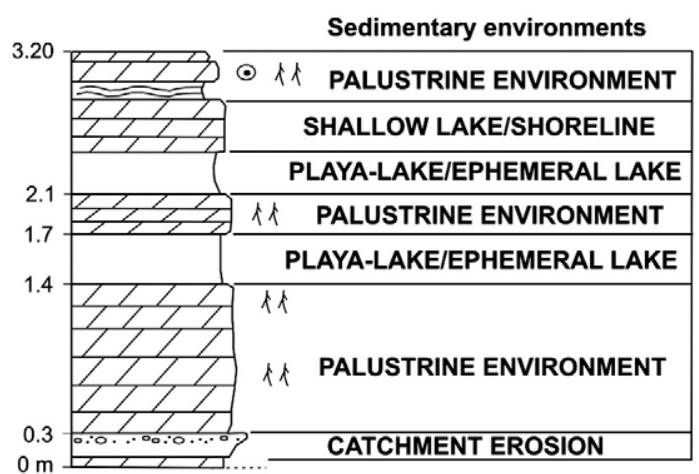

\section{LEGEND}

\section{Lithology}

\begin{tabular}{|c|c|}
\hline 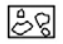 & Coarse gravel bearing volcarenite \\
\hline$\therefore$ & Medium to fine gravel bearing volcarenite \\
\hline & Dolomicrites \\
\hline & Marl \\
\hline & sils \\
\hline & Vertebrate bones \\
\hline & Vegetal debris \\
\hline$\theta$ & Microfossils \\
\hline$\odot$ & Oncolite \\
\hline
\end{tabular}

Fig. 8. A. Stratigraphic section of Las Higueruelas Lake; an ancient hard-substrate maar lake (from Hoyos et al., 1984; Alberdi, 1984). B. Stratigraphic section of Cantarranas is representative of an ancient soft-substrate maar lake. Valverde study site (CCVF, Ciudad Real). 
A

E

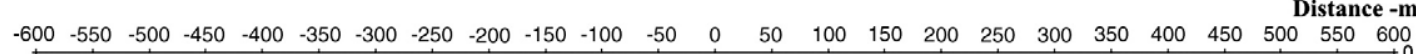

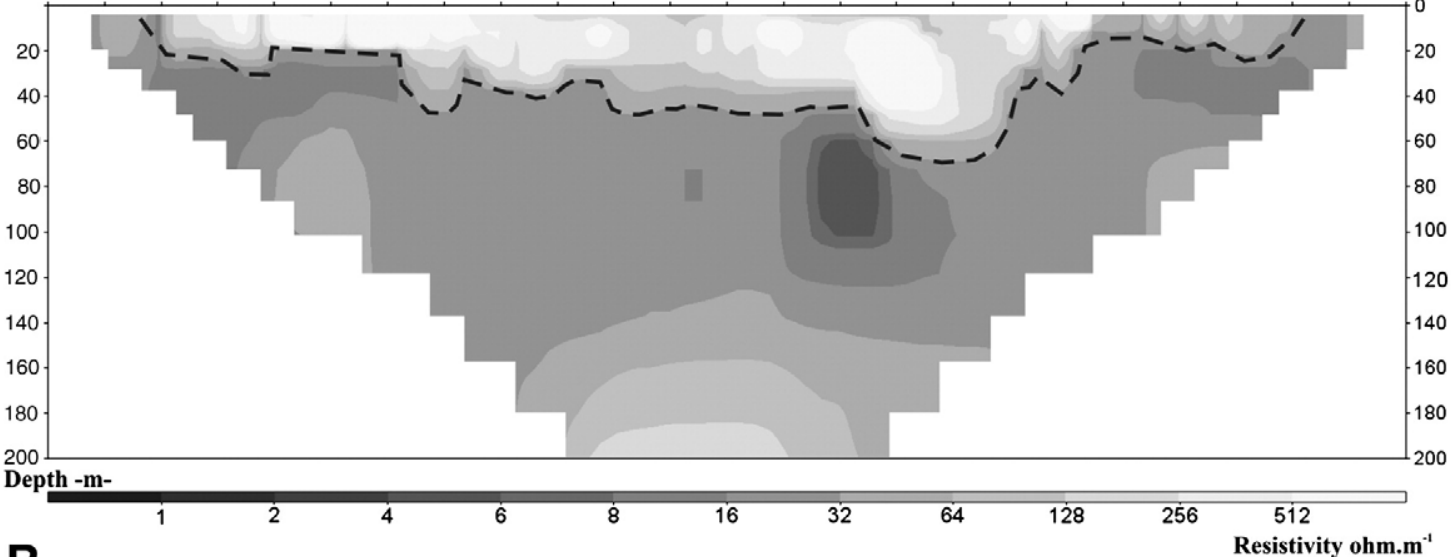

B

E Galiana maar lake basin

W

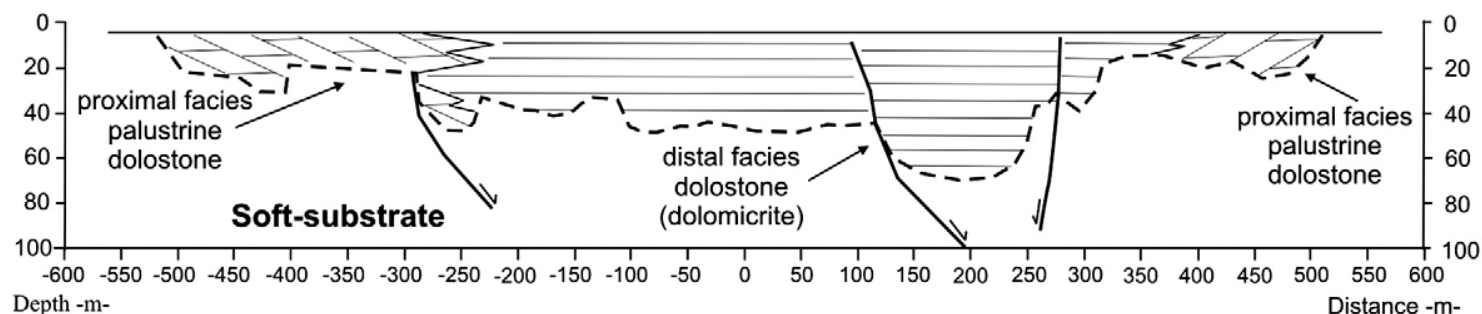

Fig. 9. A. Galiana maar lake basin (intermittent line) was reconstructed from electrical tomography interpretation of the ET-G-1 profile showed in Fig. 4. B. Subsidence of maardiatreme is interpreted by the TE profile. Galiana circular carbonate (dolostone) outcrop is a well-preserved example of an ancient soft-substrate maar lake sedimentary succession.

Ancochea, E., 1983. Evolución espacial y temporal del volcanismo reciente de España Central. Ph-D. thesis, Ed. Complutense University, Madrid.

Aranda-Gómez, J.J., Luhr, J.F., 1996. Origin of the Joya Honda maar, San Luis Potosí, Mexico. J. Volc. Geotherm. Res. 74, 1-18.

Arribas, A., Antón, M., 1997. Los carnivoros de los yacimientos pliocenos de Las Higueruelas y Piedrabuena (Ciudad Real, España). Bol. Geol. Min. 108, 111-120.

Auer, A., Martin, U., Németh, K., 2007. The Fekete-hegy (Balaton Highland Hungary) "softsubstrate" and "hard-substrate" maar volcanoes in an aligned volcanic complex implications for vent geometry, subsurface stratigraphy and the palaeoenvironmental setting. J. Volc. Geotherm. Res. 159, 225-245.

Bonadonna, F.P., Villa, J.M., 1984. Estudio geocronológico del vulcanismo de las Higueruelas. I Reunión Estratigrafía Regional Castilla-La Mancha (Albacete), vol. 3. Espacio y Sociedad, pp. 249-253.

Büchel, G., 1993. Maars of the Westeifel, Germany. In: Negendank, J.F.K., Zolitschka, B. (Eds.), Paleolimnology of European Maar Lakes. Springer-Verlag, pp. 1-13.

Caballero, M., Vilaclara, G., Rodríguez, A., Juárez, D., 2003. Short-term climatic change in lake sediments from lake Alchichica, Oriental, Mexico. Geofís. Int. 42, 529-537.

Connor, C.B., Stamatakos, J.A., Ferrill, D.A., Hill, B.E., Ofoegbu, G.I., Conway, F.M., Sagar, B., Trapp, J., 2000. Geological factors controlling patterns of small-volume basaltic volcanism: application to a volcanic hazards assessment at Yuca Mountain, Nevada. J. Geophys. Res. Sol. Earth 105, 417-432.

Crausbay, S.D., Russell, J.M., Schunurrenberger, D.W., 2006. A ca. 800-year lithologic record of drought from sub-annually laminated lake sediment, East Java. J. Paleolim. 35, 641-659.

The EUROMAARS Project. In: Creer, K.M., Thouveny, N. (Eds.), Special Issue: Quat. Sci. Rev., vol. 15. 146 pp.

Dodson, J.R., 1974. Vegetation and climatic history near Lake Keilambete, Western Victoria. Australian J. Botan. 22, 709-717.

Fisher, R.V., Schmincke, H.-U., 1984. Pyroclastic rocks. Springer Verlag, Berlin-HeidelbergNew York-Tokyo.

Francis, E.H., 1962. Volcanic neck emplacement and subsidence structures at Dunbar, southesat Scotland. Trans. R. Soc. Edin. 65, 41-58.

Galindo-Zaldívar, J., González-Lodeiro, F., Javaloy, A., 1993. Stress and paleostress in the Betic-Riff cordilleras (Miocene to the present). Tectono. 227, 105-126.

Gallardo-Millán, J.L., 2004. Evolución geodinámica de las cuencas neógenas del Campo de Calatrava (Ciudad Real) y su relación con el volcanismo reciente. Ph-D. thesis. Complutense University, Madrid.

Gallardo-Millán, J.L., Pérez-González, A., 2000. Magnetoestratigrafía del relleno neógeno en las cuencas del Campo de Calatrava (Ciudad Real). Geotemas 1,101-104.

Gallardo-Millán, J.L., Ancochea, E., Pérez-González, A., 2002. Secuencia magnetoestratigráfica y edad de los materiales volcánicos y sedimentarios de Poblete (Ciudad Real). Geogaceta 32, 35-38.
García-Cortés, A., Vegas, J., Granda, A., Galán, L., Pérez-González, A., 2007. Reconstrucción de la arquitectura lacustre cuaternaria del maar de Fuentillejo mediante tomografía eléctrica. Campo de Calatrava. In: Lario, J., Silva, P.G. (Eds.), Contribuciones al estudio del periodo Cuaternario. AEQUA, Ávila. Sección de Publicaciones de la Escuela Técnica Superior de Ingenieros Industriales. Universidad Politécnica de Madrid, pp. 191-192.

Garcin, Y., Williamson, D., Taieb, M., Vincens, A., Mathé, P.E., Majule, A., 2006. Centennial to millennial changes in maar-lake deposition during the last 45,000 years in tropical Southern Africa (Lake Masoko, Tanzania). Palaeogeog. Palaeoclim. Palaeoecol. 239, 334-354.

Gasse, F., Oldfield, F., Kroepelin, S. (Eds.), 1997. PEP III: The Pole-Ecuator-Pole Transect through Europe and Africa. PAGES Reports, pp. 97-102. http://www.pages.unibe.ch/ products/reports.html.

Gevrek, A.I., Kazanci, N., 2000. A Pleistocene, pyroclastic-poor maar from central Anatolia, Turkey: influence of a local fault on a phreatomagmatic eruption. J. Volcan. Geotherm. Res. 95, 309-317.

Hernández-Pacheco, F., 1932. Estudio de la región volcánica central de España. Mem. R Acad. Cienc. Exactas FiÂs. Nat. Madr., Ser. Cienc. Nat. 3, 1-235.

Hoyos, M., Bonadonna, F.P., Ancochea, E., de la Rubia, R., Marfil, R., 1984. Características geológicas del yacimiento de Las Higueruelas (Ciudad Real). Actas de Castilla-La Mancha. Espacio y Sociedad, vol. 3, pp. 231-240.

Kienele, J., Kyle, P.R., Self, S., Motyka, R.J., Lorenz, V., 1980. Ukinrek Maars, Alaska: 1. April 1977 eruption sequence, petrology, and tectonic settings. J. Volcan. Geotherm. Res. 7, 11-37.

Liu, J.Q., Liu, T.S., Negendank, J.F.W., 2001. The Chinese Maar Drilling Programme: a Chinese-German cooperation for paleoclimatic reconstructions. PAGES News 9, 10-11.

Lorenz, V., McBirney, A.R., Williams, H., 1970. An investigation of volcanic depressions: part III. Maars, tuff rings, tuff-cones and diatremes. NASA Progress Rpt. (NGR-38003 012), Houston, Texas, pp. 1-198.

Lorenz, V., 1971. Collapse structures in the Permian of Saar-Nahe-area, southwest Germany. Geol. Runds. 60, 924-948.

Lorenz, V., 1975. Formation of phreatomagmatic maar-diatreme volcanoes and its relevance to kimberlite diatremes. Phis. Chem. of the Earth 9, 17-27.

Lorenz, V., 1985. Maars and diatremes of phreatomagmatic origin: a review. Trans. Geol. Soc. South Africa 88, 459-470.

Lorenz, V., 1986. On the growth of maars and diatremes and its relevance to the formation of tuff-rings. Bull. Volcanol. 48, 265-274.

Lorenz, V., 2000. Formation of maar-diatreme volcanoes. Terra Nostra 2000/6, 284-291.

Lorenz, V., 2002. Hard rock and soft rock environments of explosive phreatomagmatic monogenetic volcanism. In: Ulrych, J., Cajz, V., Adamovic, J., Bosak, P. (Eds.), Hibsch 2002 Symposium. Czech Geological Survey, Prague, Tepla near Trebenice, Usti nad Labem, Marianske Lazne (Czech Republic), p. 89.

Lorenz, V., 2003. Maar-diatreme volcanoes, their formation, and their setting in hardrock and soft-rock environments. Geolines-Journal of the Geological Institute of AS Czech Republic 15, 72-83. 
Table 2

Measurements made on soft-rock maar craters and their maar lakes from Campo de Calatrava Volcanic Field.

\begin{tabular}{|c|c|c|c|c|c|c|c|c|c|}
\hline$D \max$ & $D \min$ & $d \max$ & $d \min$ & Mean $R$ & Mean $r$ & $R / r$ & $S$ & $s$ & $S / s$ \\
\hline 1200 & 800 & 750 & 300 & 500 & 262 & 1.91 & 785,400 & 216,476 & 3.63 \\
\hline 1500 & 1250 & 950 & 550 & 688 & 375 & 1.83 & $1,487,058$ & 441,787 & 3.37 \\
\hline 1350 & 850 & 750 & 400 & 580 & 288 & 2.01 & 950,334 & 260,577 & 3.65 \\
\hline 250 & 1000 & 600 & 500 & 566 & 275 & 2.06 & $1,006,430$ & 237,584 & 4.24 \\
\hline 1250 & 1000 & 400 & 400 & 566 & 200 & 2.83 & $1,006,430$ & 125,664 & 8.01 \\
\hline 1400 & 1250 & 800 & 300 & 663 & 275 & 2.41 & $1,380,950$ & 237,584 & 5.81 \\
\hline 700 & 650 & 300 & 250 & 338 & 138 & 2.45 & 358,909 & 59,829 & 6.00 \\
\hline 1500 & 1300 & 650 & 600 & 700 & 313 & 2.24 & $1,539,384$ & 307,779 & 5.00 \\
\hline 1350 & 1050 & 400 & 350 & 600 & 188 & 3.19 & $1,130,976$ & 111,037 & 10.19 \\
\hline 750 & 700 & 400 & 300 & 363 & 175 & 2.07 & 413,965 & 96,212 & 4.30 \\
\hline 750 & 550 & 300 & 250 & 325 & 138 & 2.36 & 331,831 & 59,829 & 5.55 \\
\hline 1100 & 950 & 600 & 500 & 513 & 275 & 1.87 & 826,772 & 237,584 & 3.48 \\
\hline 1100 & 900 & 600 & 450 & 500 & 263 & 1.90 & 785,400 & 217,301 & 3.61 \\
\hline 2000 & 1500 & 1000 & 750 & 888 & 425 & 2.09 & $2,477,290$ & 567,451 & 4.37 \\
\hline 1800 & 1500 & 700 & 600 & 825 & 325 & 2.54 & $2,138,251$ & 331,831 & 6.44 \\
\hline 1250 & 950 & 550 & 400 & 550 & 238 & 2.31 & 950,334 & 177,953 & 5.34 \\
\hline 1000 & 650 & 650 & 450 & 413 & 150 & 2.75 & 535,850 & 70,686 & 7.58 \\
\hline 1200 & 1000 & 950 & 650 & 550 & 325 & 1.69 & 950,334 & 331,881 & 2.86 \\
\hline 1050 & 950 & 550 & 400 & 500 & 238 & 2.10 & 785,400 & 177,953 & 4.41 \\
\hline 1000 & 700 & 650 & 450 & 425 & 275 & 1.55 & 567 & 237,584 & 2.39 \\
\hline 550 & 400 & 250 & 100 & 238 & 88 & 2.70 & 177 & 4,329 & 7.31 \\
\hline 850 & 800 & 400 & 350 & 413 & 188 & 2.20 & 535,860 & 111,037 & 4.83 \\
\hline 1600 & 1250 & 1150 & 700 & 713 & 463 & 1.54 & $1,597,092$ & 673,462 & 2.37 \\
\hline 900 & 800 & 600 & 550 & 425 & 288 & 1.48 & 567,451 & 260,577 & 2.18 \\
\hline 1300 & 1100 & 950 & 750 & 600 & 425 & 1.41 & 1,130 & & 1.99 \\
\hline 1200 & 1000 & 700 & 650 & 550 & 338 & 1.63 & 950,334 & 472,949 & 2.01 \\
\hline 650 & 550 & 500 & 450 & 300 & 175 & 1.71 & 282,744 & 96,211 & 2.94 \\
\hline 300 & 700 & 500 & 450 & 375 & 238 & 1.58 & 441 & 177,953 & 2.48 \\
\hline 1000 & 650 & 350 & 250 & 413 & 200 & 2.07 & 535 & 125,664 & 4.26 \\
\hline 1000 & 850 & 500 & 400 & 463 & 223 & 2.08 & 673 & 6,229 & 4.31 \\
\hline 700 & 600 & 400 & 350 & 325 & 188 & 1.73 & 331,881 & 111,037 & 2.99 \\
\hline 1100 & 750 & 550 & 400 & 466 & 238 & 1.96 & 682,217 & 177,953 & 3.83 \\
\hline 1250 & 1100 & 800 & 700 & 588 & 376 & 1.56 & $1,086,189$ & 444,147 & 2.45 \\
\hline 1400 & 1050 & 550 & 450 & 613 & 250 & 2.45 & 1,18 & & 6.01 \\
\hline 550 & 500 & 350 & 250 & 263 & 150 & 1.75 & 301 & 686 & 3.07 \\
\hline 1600 & 850 & 1050 & 350 & 613 & 350 & 1.75 & $1,180,516$ & 384,846 & 3.07 \\
\hline 750 & 350 & 150 & 150 & 275 & 75 & 3.67 & 237 & 17,672 & 13.44 \\
\hline 750 & 650 & 500 & 350 & 350 & 213 & 1.64 & & 303,592 & 1.27 \\
\hline 1550 & 1100 & 850 & 600 & 663 & 363 & 1.83 & $1,380,950$ & 413,965 & 3.34 \\
\hline 1000 & 900 & 650 & 450 & 475 & 275 & 1.73 & 708,823 & 37,583 & 2.98 \\
\hline 1250 & 600 & 900 & 250 & 463 & 288 & 1.61 & 673,462 & 0,577 & 2.58 \\
\hline 2250 & 1750 & 1400 & 500 & 1000 & 480 & 2.08 & 3,141 & 723 & 4.34 \\
\hline 1000 & 600 & 400 & 300 & 400 & 175 & 2.29 & & 212 & 5.22 \\
\hline 1550 & 1350 & 700 & 500 & 730 & 300 & 2.43 & $1,674,159$ & 282,744 & 5.92 \\
\hline 900 & 600 & 600 & 300 & 375 & 225 & 1.67 & 441,787 & 159,043 & 2.78 \\
\hline 750 & 750 & 400 & 250 & 375 & 163 & 2.30 & 441,787 & 83,469 & 5.29 \\
\hline 2500 & 1400 & 1550 & 800 & 975 & 588 & 1.66 & $2,986,483$ & $1,086,189$ & 2.75 \\
\hline 950 & 600 & 600 & 200 & 388 & 200 & 1.94 & 472,949 & 125,664 & 3.76 \\
\hline 1100 & 750 & 650 & 400 & 463 & 263 & 1.76 & & & 3.10 \\
\hline 1600 & 1350 & 650 & 500 & 737 & 363 & 2.03 & $1,706,420$ & 413,965 & 4.12 \\
\hline 1350 & 1100 & 800 & 650 & 625 & 288 & 2.17 & $1,227,187$ & 260,577 & 4.71 \\
\hline 1300 & 1100 & 800 & 650 & 550 & 363 & 1.52 & 950,334 & 413,965 & 2.30 \\
\hline 1050 & 1000 & 650 & 600 & 513 & 313 & 1.64 & 826,772 & 307,779 & 2.69 \\
\hline 650 & 600 & 600 & 350 & 313 & 238 & 1.32 & 307,779 & 177,953 & 1.73 \\
\hline 1250 & 1150 & 1000 & 450 & 600 & 363 & 1.65 & $1,130,976$ & 413,965 & 2.73 \\
\hline 1400 & 900 & 1000 & 650 & 575 & & & $1,038,691$ & & 1.94 \\
\hline 900 & 450 & 600 & 300 & 338 & 225 & 1.50 & 177,953 & 159,043 & 1.12 \\
\hline 1600 & 1550 & 650 & 650 & 788 & 325 & 2.42 & $1,950,758$ & 331,831 & 5.88 \\
\hline 2000 & 1550 & 800 & 650 & 888 & 368 & 2.41 & $2,477,290$ & 411,688 & 6.02 \\
\hline 2750 & 1600 & 1600 & 1150 & 1088 & 688 & 1.58 & $3,718,850$ & $1,487,057$ & 2.50 \\
\hline 1150 & 850 & 550 & 500 & 500 & 263 & 1.90 & 785,400 & 217,301 & 3.61 \\
\hline 2932 & 1000 & 1000 & 900 & 1966 & 950 & 2.07 & $8,809,258$ & $2,835,294$ & 3.11 \\
\hline 4433 & 1725 & 1724 & 1250 & 3079 & 1487 & 2.07 & $21,883,112$ & $6,946,608$ & 3.15 \\
\hline 4300 & 1600 & 1600 & 1250 & 2950 & 1425 & 2.07 & $19,820,831$ & $6,379,411$ & 3.11 \\
\hline 1890 & 800 & 800 & 500 & 1345 & 650 & 2.07 & $4,124,002$ & $1,327,326$ & 3.11 \\
\hline 2358 & 850 & 850 & 700 & 1604 & 775 & 2.07 & $5,862,671$ & $1,886,923$ & 3.11 \\
\hline
\end{tabular}

For each soft-rock maar identified in the CCVF, values of maximum and minimum diameters have been measured ( $D$ max and $D$ min, measured from the crest of the tephra ring). Mean radius $(R)$ is calculated as the half of the diameters. $d \max , d \min$ and $r$ are values corresponding to soft-rock maar lakes. The average surface area $(S)$ for craters and their associated lakes $(s)$ was estimated. All measurements were expressed on meters.
Lorenz, V., Goth, K., Suhr, P., 2003. Maar-Diatrem-Vulkanismus - Ursachen und Folgen. Die Guttauer Vulkangruppe in Ostsachsen als Beispiel für die komplexen Zusammenhänge. Z. geol. Wiss., Berlin 31, 267-312.

Lücke, A., Brauer, A., 2004. Biogeochemical and micro-facial fingerprints of ecosystem response to rapid Late Glacial climatic changes in varved sediments of Meerfelder Maar (Germany). Palaeogeogr. Palaeoclimatol. Palaeoecol. 211,139-155

Martín-Serrano, A., Vegas, J., García-Cortés, A., Granda, A., Galán, L., Martín-Alfageme, S., Rubio, F.M., García-Lobón, J.L., Ibarra, P.I., Pérez-González, A., Gallardo-Millán, J.L., 2007. Tipología de los maares del Campo de Calatrava mediante criterios geomorfológicos, geofísicos y sedimentarios de sus registros lacustres asociados. In: Lario, J., Silva, P.G. (Eds.), Contribuciones al estudio del periodo Cuaternario. AEQUA, Âvila. Sección de Publicaciones de la Escuela Técnica Superior de Ingenieros Industriales. Universidad Politécnica de Madrid, pp. 205-206.

Mingram, J., Schettler, G., Nowaczyk, N., Luo, X., Lu, H., Liu, J., Negendank, J., 2004. The Huguang maar lake-a high resolution palaeoenvironmental and palaeoclimatic changes over the last 78,000 years from South China. Quat. Int. 122, 85-107.

Muñoz, A., de Vicente, G., 1998. Origen y relación entre las deformaciones y esfuerzos alpinos de la zona centro-oriental de la Península Ibérica. Rev. Soc. Geol. España 11, 57-70.

Negendank, J.F.K., Zolitschka, B. (Eds.), 1993. Paleolimnology of European Maar Lakes. Springer-Verlag.

Németh, K., Martin, U., 2007. Shalow sill and dyke complex in western Hungary as a possible feeding system of phreatomagmatic volcanoes in "soft-rock" environment. J. Volcan. Geotherm. Res. 159, 138-152.

Németh, K., Martin, U., Harangi, S.Z., 2001. Miocene phreatomagmatic volcanism at Tihany (Pannonian Basin, Hungary). J. Volcan. Geotherm. Res. 111, 111-135.

Németh, K., Goth, K., Martin, U., Csillag, G., Suhr, P., 2008. Reconstructing paleoenvironmental, eruption mechanism and paleomorphology of the Pliocene Pula maar, (Hungary). J. Volcan. Geotherm. Res. 177, 441-456.

Pirrung, M., Fischer, C., Büchel, G., Gaupp, R., Lutz, H., Neuffer, F.O., 2003. Lithofacies succession of maar crater deposits in the Eifel area (Germany). Terra Nova 15, 125-132.

Pirrung, M., Büchel, G., Lorenz, V., Treutler, H.C., 2008. Post-eruptive development of the Ukinrek East Maar since its eruption in 1977 A.D. in the periglacial area of southwest Alaska. Sed. 55, 305-334.

Platt, N.H., Wright, V.P., 1991. Lacustrine carbonates: facies models, facies distribution and hydrocarbon aspects. In: Anadón, P., Cabrera, L., Kelts, K. (Eds.), Lacustrine Facies Analysis: Special Publication International Association of Sedimentologists, vol. 13, pp. 57-74.

Poblete, M.A., 1995. El relieve volcánico del Campo de Calatrava (Ciudad Real). Junta de Comunidades de Castilla-La Mancha Ed., Gijón.

Roberts, N., Reed, J.M., Leng, M.J., Kuzucuoglu, C., Fontugne, M., Bertaux, J., Woldring, H., Bottema, S., Black, S., Hunt, E., Karabiyikoglu, M., 2001. The tempo of Holocene climatic change in eastern Mediterranean region: new high-resolution crater-lake sediment data from central Turkey. The Holocene 11, 721-736.

Schmincke, H.-U., 1988. Vulkane im Laacher See-Gebiet, ihre Entstehung und heutige Bedeutung. Bode, Haltern, pp. 1-119.

Schulz, R., Buness, H., Gabriel, G., Pucher, R., Rolf, C., Wiederhold, H., Wonik, T., 2005. Detailed investigation of preserved maar structures by combined geophysical surveys. Bull. Volcan. 68, 95-106.

Self, S., Kienle, J., Huot, J.-P., 1980. Ukinrek Maars, Alaska: II. Deposits and formation of the 1977 crater. J. Volcan. Geotherm. Res. 7, 39-65.

Sohn, Y.K., Park, K.H., 2004. Composite tuff ring/cone complexes in Jeju Island, Korea: possible consequences of substrate collapse and vent migration. J. Volcan. Geotherm. Res. 141, 157-175.

Stoffers, P., Holdship, S.A., 1975. Diagenesis of sediment in an alkaline lake: Lake Manyara, Tanzania. Proc. IXth Int. Conf. of Sedimentology. Nice 7, 211.

Suhr, P., Goth, K., Lorenz, V., Suhr, S., 2006. Long lasting subsidence and deformation in and above maar-diatreme volcanoes - a never ending story. Zeitsch. Gessells. Geowissens. 157, 491-511.

Vegas, J., García-Cortés, A., Galán, L., Pérez-González, A., Martín-Serrano, A., 2006. El registro sedimentario lacustre del maar de Fuentillejo (Ciudad Real). Bol. Geol. Min. 117, 339-349.

Vegas, J., Martín-Serrano, A., García-Cortés, A., Granda, A., Martín-Alfageme, S., Rubio, F.M., García-Lobón, J.L., Ibarra, P.I., Galán, L., Pérez-González, A., Gallardo-Millán, J.L., Bernat, M., 2007. Morphotectonic setting of maar lakes in central Spain (Campo de Calatrava Volcanic Field). Abstracts of 4th International Limnogeology Congress (ILIC 2007): Limnogeology: Tales of an Evolving Earth, p. 155.

Wagstaff, B.E., Kershaw, A.P., O Sullivan, P.B., Harle, K.J., Edwards, J., 2001. An Early to Middle Pleistocene palynological record from volcanic crater of Pejark Marsh, Western Plain of Victoria, southeastern Australia. Quat. Int. 83-85, 211-232.

White, J.D.L., 1991. The depositional record of small, monogenetic volcanoes within terrestrial basins. SEPM Spec. Pub. 45, 155-171.

White, J.D.J., McClintock, M.K., 2001. Immense vent complex marks flood-basalt eruption in a wet, failed rift: Coombs Hills, Antarctica. Geol. 29, 935-938.

Wohletz, K.H., Zimanowski, B., 2000. Physics of phreatomagmatism; Part 1: Explosion physics. Terra Nostra 2000/6, 515-523.

Zolitschka, B., Schäbitz, F., Lücke, A., Corbella, H., Ercolano, B., Fey, M., Haberzettl, T., Janssen, S., Maidana, N., Mayr, C., Ohlendorf, C., Oliva, G., Paez, M.M., Schleser, G.H., Soto, J., Tiberi, P., Wille, M., 2006. Crater lakes of the Pali Aike next term Volcanic Field as key sites for paleoclimatic and paleoecological reconstructions in southern Patagonia, Argentina. J. South Am. Earth Sci. 21, 294-309. 